\title{
KECENDERUNGAN MENYALAHKAN KORBAN (VICTIM-BLAMING) DALAM KEKERASAN SEKSUAL TERHADAP PEREMPUAN SEBAGAI DAMPAK KEKELIRUAN ATRIBUSI
}

\section{THE TENDENCY OF VICTIM-BLAMING IN SEXUAL VIOLENCE AGAINST WOMEN AS THE IMPACT OF ATTRIBUTION ERROR}

\author{
Erika Putri Wulandari ${ }^{1}$, Hetty Krisnani ${ }^{2}$ \\ ${ }^{1}$ Program Studi Sarjana Ilmu Kesejahteraan Sosial, Universitas Padjadjaran \\ 2Pusat Studi CSR, Kewirausahaan Sosial \& Pemberdayaan Masyarakat, Universitas Padjadjaran \\ erika19002@mail.unpad.ac.id; hettykrisnani@yahoo.com
}

\begin{abstract}
ABSTRAK
Korban dari kekerasan seksual terhadap perempuan sering kali merasa tidak aman untuk melaporkan tindakan kejahatan yang terjadi pada mereka, malahan mereka cenderung disalahkan oleh berbagai macam pihak, termasuk yang memiliki otoritas - polisi, pengacara, hakim, dan tenaga medis. Penelitian ini bertujuan mengkaji keterkaitan mitos pemerkosaan dengan kepercayaan pada dunia yang adil pada kasus kekerasan seksual terhadap perempuan, diikuti analisis menggunakan pendekatan teori atribusi. Metode yang digunakan adalah studi literatur. Hasil penelitian menunjukkan bahwa terjadi kekeliruan dalam pengatribusian kesalahan berdasarkan mitos pemerkosaan dan kepercayaan pada dunia yang adil. Ditemukan pula perbedaan respon antara pemerkosaan oleh orang asing dan oleh orang yang dikenal korban, bahwa korban dari pemerkosaan oleh orang asing disebut-sebut sebagai "korban sesungguhnya". Sejumlah implikasi praktis sebagai usaha meminimalisir perilaku menyalahkan korban disertakan pada tulisan ini.
\end{abstract}

Kata kunci: Menyalahkan Korban, Kekerasan terhadap Perempuan, Kekerasan Seksual, Mitos Pemerkosaan, Kepercayaan pada Dunia yang Adil

\section{ABSTRACT}

Victims of sexual violence against women often feel unsafe when reporting attacks against them, instead they tend to be re-victimized by a variety of parties, including the authorities - police, lawyers, judges and medical personnel. This study intends to examine the relationship between rape myths and just world beliefs with sexual violence against women, followed by analysis using the approach of attribution theory. The method used in this study is literature review. The results showed that there was an error of blame attribution based on the rape myths and just world beliefs. There were also differences in responses between stranger rape and acquaintance/date rape, indicating the victims of stranger rape are what makes the "real victim". Some practical implications to help minimizing victim-blaming behavior are included in this paper.

Keywords: Victim Blaming, Violence against Women, Sexual Violence, Rape Myths, Just World Beliefs 


\begin{tabular}{|l|l|l|l|l|}
\hline Share: Social Work Jurnal & VOLUME: 10 & NOMOR: 2 & HALAMAN: $135-145$ & $\begin{array}{c}\text { ISSN: 2339-0042 }(p) \\
\text { ISSN: 2528-1577 }(e) \\
\text { DOI: } 10.24198 / \text { share.v10i1.26896 }\end{array}$ \\
\hline
\end{tabular}

\section{PENDAHULUAN}

\section{KEKERASAN TERHADAP PEREMPUAN}

Kekerasan terhadap perempuan adalah "manifestasi dari relasi kekuasaan yang tidak merata secara historis antara laki-laki dan perempuan", dan "salah satu mekanisme sosial penting di mana terjadinya subordinasi perempuan atas laki-laki" (Harnoko, 2010; Kartika, 2015; Maryam, 2017; United Nations General Assembly, 1993;). Syafe'i (2015) mengatakan subordinasi perempuan adalah posisi 'penomorduaan' perempuan, yang berarti perempuan lebih lemah/rendah dari laki-laki secara kedudukan, fungsi, dan peran. Selain subordinasi, Guamarawati (2009) berpendapat perempuan masih menanggung beban sebagai kelompok yang terpinggirkan, seperti diskriminasi, pelecehan, eksploitasi, dan lain sebagainya. Lebih lanjut, kekerasan terhadap perempuan melibatkan kekerasan berbasis gender yang akan berakhir pada bahaya atau penderitaan fisik, seksual, atau psikologis bagi perempuan, termasuk ancaman, pemaksaan, dan perampasan kemerdekaan secara sewenang-wenang, baik yang terjadi di depan umum atau dalam kehidupan pribadi. Sesuai dengan definisi yang telah menyebutkan ketimpangan relasi kekuasaan antara laki-laki dan perempuan secara historis, kekerasan terhadap perempuan bisa dikatakan berakar dari pembagian peran yang bahkan sudah dilakukan sejak zaman pra-aksara. Fakta biologis yang menyatakan tenaga laki-laki jauh lebih kuat daripada perempuan membuat manusia sedari dulu mengasosiasikan peran perburuan hewan liar sebagai tugas laki-laki, sedangkan perempuan bertugas dalam merawat dan membesarkan anak, juga menjaga api khususnya ketika mereka tidak lagi hidup nomaden. Guamarawati (2009) memperkuat pernyataan ini dengan menyebutkan bahwa tanpa kita sadari pembagian peran itu melahirkan mekanisme sosial mengenai laki-laki yang lebih unggul dalam banyak hal ketimbang perempuan, kemudian laki-laki menyalahgunakan kekuasaan yang dimilikinya untuk melakukan tindakan kekerasan. Tindakan kekerasan ini dikonstruksikan melewati interaksi sosial antara masyarakat patriarki-dominasi sistem dan kekuasaan oleh laki-laki (Harnoko, 2010).
Terdapat variasi jenis-jenis kekerasan terhadap perempuan, tidak terbatas hanya pada sebagian kecil yang ditampilkan, dan beberapa di antaranya adalah: a) kekerasan dalam rumah tangga-termasuk kekerasan ekonomi, kekerasan psikologis, kekerasan emosional, kekerasan fisik, dan kekerasan seksual; b) femisida atau pembunuhan perempuan yang disengaja karena mereka adalah perempuan-termasuk pembunuhan demi menjaga kehormatan, contohnya kehormatan keluarga; c) kekerasan seksual-termasuk pelecehan seksual, pemerkosaan, pemerkosaan korektif atau suatu bentuk perkosaan yang dilakukan terhadap seseorang atas dasar orientasi seksual, dan budaya pemerkosaan; d) perdagangan manusia, e) mutilasi alat kelamin perempuan, f) pernikahan anak, dan g) kekerasan berbasis digital-termasuk cyberbullying, pesan bernada seksual yang tidak disetujui kedua belah pihak atau tidak meraih konsensus bersama, dan doxing atau menyebarluaskan informasi pribadi di publik (United Nations Entity for Gender Equality and the Empowerment of Women, n.d.). Ada pun pada tulisan ini, peneliti mempersempit lingkup penelitian pada kekerasan seksual yang terjadi terhadap perempuan. Peneliti memulai dari pemberian definisi mengenai apa itu kekerasan terhadap perempuan, kekerasan seksual dan perilaku menyalahkan korban (victim blaming), kemudian dilanjutkan pemaparan hasil studi literatur tentang faktor-faktor yang memengaruhinya setelah penyajian metode.

\section{KEKERASAN SEKSUAL}

Kekerasan seksual didefinisikan sebagai perilaku yang mengarah pada ajakan seksual, seperti menyentuh, meraba-raba, mencium dan/atau melakukan perilaku lain yang tidak diinginkan oleh korban, memaksa korban mengkonsumsi konten pornografi, lelucon dengan intensi seksual, mempermalukan dan melecehkan dengan menyebut aspek jenis kelamin korban, dan memaksa orang lain berhubungan seks tanpa persetujuan korban; aktivitas seksual terjadi akibat pemaksaan (Anisa \& Santoso, 2020; Poerwandari, 2000). World Health Organization (2012) menyebutkan bahwa kekerasan seksual meliputi tindakan dari pelecehan verbal hingga 


\begin{tabular}{|c|c|c|c|c|}
\hline Share: Social Work Jurnal & VOLUME: 10 & NOMOR: 2 & HALAMAN: $135-145$ & $\begin{array}{c}\text { ISSN: 2339-0042 (p) } \\
\text { ISSN: 2528-1577 (e) } \\
\text { DOI: 10.24198/share.v10i1.26896 }\end{array}$ \\
\hline
\end{tabular}

penetrasi paksa atau tanpa mengindahkan persetujuaan kedua belah pihak, serangkaian aksi pemaksaan, seperti intimidasi, tekanan sosial, hingga kekerasan fisik. Tindakan kejahatan ini terjadi tidak memandang gender tertentu, namun riset membuktikan kekerasan seksual kerap dialami perempuan dibandingkan laki-laki (Gravelin et al., 2019; Oktaviani \& Azeharie, 2020), dan menjadi pemicu kuat mengapa berbagai sumber seperti literatur lebih banyak membahas masalah tersebut, terutama jenis dari kekerasan seksual dapat diuraikan lagi sehingga sangat masuk akal jika peneliti-peneliti lain tertarik pada hal yang sama, selain eksistensi atas urgensi itu sendiri. Akan tetapi, peneliti hanya membahas tentang pemerkosaan yang dilakukan orang asing (stranger rape) dan pemerkosaan yang dilakukan kenalan (acquaintance/date rape)-misalnya, teman akrab, teman kencan, atau rekan sekelas-pada tulisan ini, seperti mengapa respon pelaku tindakan kejahatan dan orang ketiga selaku pengamat bisa bervariasi.

Tercatat sebanyak 431.479 kasus kekerasan terhadap perempuan pada tahun 2019 di Indonesia, dan merupakan peningkatan sebanyak $6 \%$ dari tahun sebelumnya yang menyentuh 406.178 kasus (Catatan Tahunan (CATAHU) Komnas Perempuan, 2020). Khususnya untuk ranah kekerasan seksual terhadap perempuan, tercatat terjadi sejumlah penurunan pada tahun terkait: 5.280 kasus di tahun 2018 menjadi 4.898 kasus di tahun 2019. Meskipun begitu, data ini dipercaya tidak merepresentasikan situasi sebenarnya karena hanya berbasis pada laporan yang masuk saja. Hal ini kemudian dikaitkan dengan fenomena gunung es, di mana data yang berhasil dikumpulkan tidak sesuai dengan yang sebenarnya berada di lapangan. Korban dari kekerasan seksual terhadap perempuan cenderung enggan untuk melaporkan kejadian yang menimpa mereka disebabkan oleh ketakutan atas respon yang akan mereka terima setelahnya. Lebih lanjut, tidak ada yang mampu meyakinkan keuntungan berada di pihak korban ketika mereka melaporkan kronologi peristiwa tersebut, karena pihak yang memiliki otoritas sekali pun kadang-kadang justru kembali menyalahkan dirinya. Korban disudutkan dengan rasa bersalah, rasa tidak aman, dan rasa malu sekaligus yang berpotensi memperparah keadaan psikisnya dalam jangka panjang.

\section{PERILAKU MENYALAHKAN KORBAN (VICTIM BLAMING)}

Perilaku menyalahkan korban (victim blaming) terjadi ketika korban dari suatu tindakan kejahatan justru disalahkan dan bertanggung jawab untuk kejahatan yang mereka dapatkan, dan sering berlaku dalam konteks kekerasan seksual. Pada isu ini, beberapa parameter menentukan seberapa layak seorang perempuan disalahkan, contohnya: ketersediaan melakukan kontak romantis berdasarkan kesetujuan kedua belah pihak, jenis pakaian yang dipakai saat kejadian, dan mengundang atau menemani teman kencan ke tempat tinggalnya (Bongiorno et al., 2010; Perilloux et al., 2014). Bentuk-bentuk menyalahkan korban berupa tidak memercayai cerita korban, menyalahkan korban, merendahkan tingkat keparahan serangan yang diterima, dan perlakuan tidak sesuai pasca tindakan kejahatan oleh pihak yang memiliki otoritas (Campbell \& Raja, 1999). Pihak yang menyalahkan korban meliputi orang terdekat korban dimulai dari teman, keluarga, kerabat, bahkan pihak yang bekerja di instansi tertentu-polisi, pengacara, hakim, dan tenaga medis (Campbell \& Raja, 1999), namun sebuah hubungan pertemanan biasanya berperan mengerahkan keberpihakan pada korban. Tidak jarang orang yang tidak dikenal korban juga ikut menyalahkan korban, terlebih lagi jika tindakan kekerasan seksual tersebut masuk ke dalam pemberitaan, baik regional maupun nasional. Hal ini amat mencengangkan juga mengkhawatirkan karena orang yang sama sekali tidak mengenal korban justru ikut berprasangka buruk tentangnya. Kita dapat menyebut pihak-pihak ini sebagai orang ketiga selaku pengamat, yakni orang-orang yang tidak menyaksikan aksi kejahatan secara langsung.

Condry (2010; dalam Campbell \& Raja, 1999) menyatakan bahwa korban yang pada realitanya tidak semestinya 'dihukum' dan dikenakan tindak pidana, harus melewati trauma ulang melalui tanggapan individu dan institusi atas tindakan keji yang diterimanya. Oleh sejumlah peneliti, perilaku menyalahkan korban dihitung sebagai rupa viktimisasi sekunder (secondary victimization) atau reviktimisasi (George \& Martinez, 2002; Maier, 2012), yakni usaha menstigmatisasi korban serta trauma, 


\begin{tabular}{|c|c|c|c|c|}
\hline Share: Social Work Jurnal & VOLUME: 10 & NOMOR: 2 & HALAMAN: $135-145$ & $\begin{array}{c}\text { ISSN: 2339-0042 (p) } \\
\text { ISSN: 2528-1577 (e) } \\
\text { DOI: 10.24198/share.v10i1.26896 }\end{array}$ \\
\hline
\end{tabular}

kesusahan, dan keterasingan yang dirasakannya akibat tanggapan yang diterimanya tidak sesuai dengan apa yang diharapkan, cenderung menyalahkannya kembali, dan biasanya diasosiasikan bersama aparat pemerintah. Viktimisasi sekunder berlangsung cukup panjang dan bersifat kompleks, berakar dari sifat negatif, menghakimi perilaku yang diarahkan pada korban (Williams, 1984; dalam Campbell \& Raja, 1999). Respon tersebut sejak lama dianggap penyebab proses pelaporan tindakan kekerasan seksual terhadap perempuan yang tidak transparan (Bongiorno et al., 2010; Maier, 2012).

Perilaku menyalahkan korban (victim blaming), di penelitian-penelitian sebelumnya, sering ditelaah keterkaitannya dengan mitos pemerkosaan (rape myths) dan kepercayaan pada dunia yang adil (just world beliefs). Di dalam bukunya, Burt (1980; dalam Yamawaki, 2009) menyebutkan definisi mitos pemerkosaan (rape myths) adalah, "prasangka, stereotip, atau kekeliruan tentang pemerkosaan, korban pemerkosaan, dan pemerkosa" lalu Lerner \& Simmons (1966) mengklaim setiap individu memiliki dorongan memercayai keadilan di dunia sehingga mereka berusaha meningkatkan kepantasan (misalnya, kompetensi, kontrol dan kapasitas) untuk tinggal di dalamnya dengan rasa percaya diri. Dampaknya, individu berpacu menganggap dunianya yang paling ideal sesuai standar dan nilai-nilai yang dianut. Jika terjadi penyimpangan dari kedua hal tersebut, mereka merasa terancam sehingga mengunggulkan diri mereka sendiri daripada orang lain. Di saat ini, timbul potensi menyalahkan orang lain.

Dalam tulisan ini, peneliti tertarik dengan hubungan antara mitos pemerkosaan (rape myths) dan kepercayaan pada dunia yang adil (just world beliefs) dalam memengaruhi kerangka berpikir individu. Nilai-nilai dan kepercayaan yang dianut berdampak pada respon atas sesuatu dalam jangka waktu yang singkat, dengan asumsi bahwa individu sering kali mengemukakan pendapat tanpa mengetahui latar belakang dari tindakan kekerasan seksual tersebut. Di samping itu, peneliti bermaksud mengkaji mitos pemerkosaan (rape myths) yang beredar di kalangan masyarakat, signifikansi variabel korban yang menjadi pertimbangan individu tentang tingkat keparahan serangan, dan distribusi peran gender. Spears \& Spohn (1996) menyebutkan terdapat suatu pemikiran manusia bahwa harus ada kesinambungan antara setiap tindakan yang mereka lakukan dengan hasil yang mereka peroleh. Mereka tidak mudah menerima sesuatu yang tidak dirasa cocok dengan konsepsi pribadi. Pada kasus ini, misalnya, perilaku korban yang tidak menolak serangan fisik mungkin diasosiasikan dengan tanggung jawab korban yang lebih berat karena dianggap sebagai konsekuensi atas perbuatan sendiri.

Penelitian ini bertujuan untuk memberikan pemahaman komprehensif melalui studi literatur terkait faktor-faktor yang memengaruhi seorang individu mengatribusi kesalahan kepada korban dari tindakan kekerasan seksual terhadap perempuan. Atribusi kesalahan ditekankan pada pendekatan teori atribusi, yang ditujukan untuk memahami proses mengatribusi suatu hal; bagaimana individu mengaitkan apa yang terjadi di lingkungan dengan respon perilaku, membuat atribusi sebab-akibat (Heider, 1958; dalam Martinko \& Mackey, 2019). Terakhir, peneliti mempertimbangkan probabilitas tindakan yang tepat untuk meminimalisir reviktimisasi korban kekerasan seksual terhadap perempuan.

\section{METODE}

Artikel ini menggunakan metode studi literatur untuk menggambarkan mengapa individu memiliki kecenderungan menyalahkan korban kekerasan seksual terhadap perempuan atas tindakan kejahatan yang menimpanya. Literatur diperoleh dari buku, jurnal, laporan, dan berita yang sesuai dengan tema yang sedang dibahas.

\section{HASIL DAN PEMBAHASAN}

Perilaku menyalahkan korban kekerasan seksual terhadap perempuan merupakan bentuk kekeliruan atribusi (Amandasari \& Margaretha, 2019), mengacu pada kecenderungan meminta pertanggungjawaban korban dari peristiwa negatif yang dialaminya. Yang dilakukan individu saat sedang berusaha mengatribusikan sesuatu ialah membuat hubungan kausalitas antara apa yang terjadi dan apa yang dipahaminya. Mengingat manusia dikelilingi budaya tertentu di lingkungannya dan manusia sendiri merupakan produk dari budaya, pemutusan sebab-akibat ikut bersandar pada keterbatasan pengetahuan dan 


\begin{tabular}{|c|c|c|c|c|}
\hline Share: Social Work Jurnal & VOLUME: 10 & NOMOR: 2 & HALAMAN: $135-145$ & $\begin{array}{c}\text { ISSN: 2339-0042 (p) } \\
\text { ISSN: 2528-1577 (e) } \\
\text { DOI: 10.24198/share.v10i1.26896 }\end{array}$ \\
\hline
\end{tabular}

nilai budaya yang memengaruhinya. Seperti yang dikemukakan Gray et al. (2010), seseorang mampu mengatribusikan suatu hal menjadi tanggung jawab dari pelaku perbuatan, antara lain dipengaruhi oleh: (1) posisi kelas sosial, gender, dan ras mereka; (2) pengalaman serupa yang dialami individu; (3) latar tempat terjadinya perkara; dan (4) keuntungan psikologis yang mungkin didapatkan melalui pengatribusian kejadian. Uniknya, proses pengatribusian ini bisa terjadi secara spontan, contohnya persepsi awal yang kita miliki saat mengetahui berita baru.

Beberapa faktor-faktor yang memengaruhi perilaku menyalahkan korban kekerasan seksual terhadap perempuan, atau bentuk dari kesalahan atribusi, berakar dari mitos pemerkosaan (rape myths) dan kepercayaan pada dunia yang adil (just world beliefs). Laki-laki dengan yang menyetujui mitos pemerkosaan dan memiliki tingginya kepercayaan pada dunia yang adil lebih banyak menyalahkan korban (Kopper, 1996). Kedua aspek ini sering kali ditemukan di penelitian-penelitian sebelumnya mengenai topik yang serupa.

\section{FAKTOR-FAKTOR YANG MEMENGARUHI PERILAKU MENYALAHKAN KORBAN}

\section{Mitos Pemerkosaan (Rape Myths)}

Budaya di Asia masih terlampau kental pengaruhnya kepada pembagian peran gender. Jika dibandingkan dengan negara-negara Barat yang lebih bisa menerima pemahaman egalitarian-pandangan yang mengatakan bahwa manusia ditakdirkan sama derajatnya, negaranegara Asia yang tidak demikian kerap berpegang teguh pada nilai-nilai konvensional atau tradisional mengenai pembagian peran gender secara otomatis. Meskipun efek modernisasi menyebabkan semakin berkurangnya pemikiran tersebut, budaya ini tidak dapat sepenuhnya dipisahkan. Hal ini senada dengan hasil penelitian yang dilakukan Yamawaki (2009) terhadap orang Jepang, menunjukkan bahwa mereka memegang peran gender tradisional lebih kuat daripada orang Amerika. Sebuah penelitian lain oleh Gray et al. (2010) menghasilkan skor tertinggi kepercayaan kepada mitos pemerkosaan oleh orang Asia yang berstatus mahasiswa asing, diikuti oleh orang Hispanik dan orang asli Amerika. Dapat ditarik sebuah pernyataan bahwa budaya seperti ini masih erat penerimaannya di individu, karena tidak semua orang Asia di luar negeri ternyata menyerap pemikiran mayoritas orang-orang Barat.

Burt (1980; dalam Yamawaki, 2009) di dalam bukunya berjudul Cultural Myths and Support for Rape menegaskan definisi mitos pemerkosaan (rape myths) adalah, "prasangka, stereotip, atau kekeliruan tentang pemerkosaan, korban pemerkosaan, dan pemerkosa." Rusyidi et al. (2020) berpendapat mitos pemerkosaan ini menuntut pertanggungjawaban korban atas tindakan provokatifnya sewaktu kejadian berlangsung, dengan anggapan kejadian nista tersebut sebenarnya bisa dihindari. Mitos pemerkosaan "menempatkan perempuan di posisi merugikan" (Bohner \& Schwarz, 1996; dalam Abrams et al., 2003). Menurut Barska (2005; dalam Sekscinska et al., 2016), peran tradisional perempuan dan laki-laki belum banyak berubah selama bertahun-tahun, meskipun ini bukan berarti meniadakan perubahan-perubahan yang terjadi. Perlu diketahui, peran gender tradisional terbentuk dari konformitas yang berlaku di masyarakat, atau hal-hal yang dirasa pantas dan tingkat keberlakuannya bergantung pada masyarakat di suatu daerah itu sendiri. Di budaya Asia, ekspektasi peran perempuan yang mengurus rumah, memasak, merawat keluarga termasuk anak-anaknya (Fiske et al., 2002) diketahui tidak dapat dipisah dari mereka. Kelompok perempuan dihubungkan dengan kemampuan natural mereka dalam hal pengasuhan. Seperti yang telah disinggung di pendahuluan, hal ini berakar jauh sekali ketika manusia berada di zaman pra-aksara.

Sebaliknya, peran tradisional laki-laki memiliki kaitan erat dengan menjadi "kepala" keluarga, bertanggung jawab memberi nafkah keluarga dan segala urusan di rumah tangga yang membutuhkan kekuatan serta keterampilan mereka, seperti ketika sebuah keluarga harus berpindah rumah, bagaimana menjaga seluruh anggota keluarga dari mara bahaya, dan lain-lain. Mereka juga sering diasosiasikan dengan kemampuan natural mereka menjadi seorang pemimpin yang mandiri dan kompetitif, bertolak belakang dengan perempuan yang dihubungkan dengan kasih sayang dan kepekaan (Sekscinska et al., 2016). Tidak mengherankan jika Guamarawati (2009) mengutip dari buku Against 


\begin{tabular}{|c|c|c|c|c|}
\hline Share: Social Work Jurnal & VOLUME: 10 & NOMOR: 2 & HALAMAN: $135-145$ & $\begin{array}{c}\text { ISSN: 2339-0042 (p) } \\
\text { ISSN: 2528-1577 (e) } \\
\text { DOI: 10.24198/share.v10i1.26896 }\end{array}$ \\
\hline
\end{tabular}

Our Will; Men, Women, and Rape karya Susan Brownmiller (1975) tentang keyakinannya bahwa kekerasan seksual terhadap perempuan memfasilitasi maskulinitas laki-laki, berakar dari kecenderungan dianggap memiliki aspek-aspek yang disebutkan sebelumnya, membuat mereka merasa lebih superior ketimbang perempuan. Sederhananya, muncul praktik standar ganda di sini. Laki-laki yang mengekspresikan hawa nafsu dan maskulinitasnya dirasa sah-sah saja.

Kepercayaan membatasi peran dan hak perempuan menjadi salah satu kontribusi tingginya penganut mitos pemerkosaan. Selain peran gender, yang termasuk stereotip adalah peran struktur budaya, kepercayaan, dan bagaimana praktiknya di lingkungan (Gravelin et al., 2019), baik lingkungan keluarga maupun masyarakat. Sebuah konsep krusial yang melekat dengan stereotip peran ini ialah seksisme, yaitu sebuah prasangka yang timbul berdasarkan gender. Seksisme juga ikut menekankan peran tradisional; perempuan yang bersandar terhadap nilai-nilai konvensional dilihat secara positif, sedangkan perempuan yang menolak nilai-nilai tersebut-seperti perempuan karier-dianggap sebaliknya (Amandasari \& Margaretha, 2019). Pada umumnya, pemahaman ini diadopsi oleh laki-laki sebab mereka merasa terancam dengan perempuan yang keluar dari nilai seharusnya, di mana yang memegang peran tersebut semestinya adalah kelompok mereka. Akibat dari rasa tidak aman ini memunculkan kemungkinan yang tinggi bagi mereka untuk tidak memercayai atau meremehkan kekerasan seksual terhadap perempuan. Namun, tidak jarang juga mereka ikut menyalahkan korban perempuan atas tindakan yang menimpa mereka karena menduga perempuan suka melebih-lebihkan masalah, terlalu emosional ketika menghadapi sesuatu, dan sengaja mencari keuntungan demi keuntungan pribadi (Bongiorno et al., 2010; Gravelin et al., 2010; lihat Abrams et al., 2003). Belum lagi, persepsi mengenai dampak psikologis yang dihasilkan dari kejadian ini sering kali dianggap kurang valid sehubungan dengan buktinya yang tidak terlihat secara nyata.

Nilai-nilai

tradisional

yang diinternalisasikan terhadap perempuan sejak dahulu tidak sekadar menjelaskan tentang karier mereka, tetapi dalam sebuah pernyataan sederhana dapat dikatakan adanya susunan aturan-aturan mengenai bagaimana mereka harus bertindak, berpakaian, berbicara, dan berperilaku berdasarkan jenis kelamin mereka. Contoh lainnya, perempuan yang mengenakan pakaian terbuka dan seksi dianggap "mengundang" pelecehan hingga kekerasan seksual (Bongiorno et al., 2010), akibatnya mereka sulit menerima dukungan penuh dari orang ketiga, sebab telah timbul citra bahwa mereka berkontribusi mendatangkan bahaya kepada diri sendiri (Amandasari \& Margaretha, 2019; Gravelin et al., 2010; Maryam, 2017; Oktaviani \& Azeharie, 2020). Khusus untuk hal ini, selain peran tradisional perempuan yang mendasarinya, terdapat faktor lain yang memengaruhi komentar kesengajaan perempuan "mengundang" peristiwa kejahatan tadi, misalnya kepercayaan pada agama tertentu.

Sejumlah penelitian mengungkapkan bahwa respon orang ketiga, selaku orang yang tidak mengalami kekerasan seksual secara langsung, ternyata juga bermacam-macam. Dari perbedaan jenisnya saja, antara stranger rape dan acquaintance/date rape, ditemukan kecenderungan menyalahkan korban lebih tinggi pada acquaintance/date rape (George \& Martinez, 2002) sebab korban telah mengenali pelaku sebelumnya, sehingga diasumsikan kejadian yang menimpanya sangat memungkinkan untuk dihindari (misalnya, "Harusnya sudah tahu sejak awal! Itu mah bukti mau sama mau). Gravelin dan rekan-rekannya menemukan bahwa $41 \%$ dari kekerasan seksual yang terjadi ternyata berjenis acquaintance/date rape. Mitos pemerkosaan menyebutkan hanya stranger rape yang terhitung sebagai "pemerkosaan sebenarnya" (Gravelin et al., 2019; Spears \& Spohn, 1996), padahal rasa nyaman yang ditawarkan kenalan korban tidak menutup kemungkinan berujung pada perilaku manipulasi, kemudian memundurkan skala kewaspadaan korban. Sering sekali kekeliruan mengatribusi kesalahan ini ikut dilakukan oleh pihak berwajib yang justru tambah menjatuhkan mental korban alih-alih membantu mereka, karena terlepas dari jabatannya, orang-orang tersebut menganut nilai dan kepercayaan yang mengarah ke mitos pemerkosaan. Hal ini diperkuat dengan penemuan Spears \& Spohn tentang para jaksa, saat menentukan proses keberlanjutan kasus kekerasan seksual terhadap 


\begin{tabular}{|c|c|c|c|c|}
\hline Share: Social Work Jurnal & VOLUME: 10 & NOMOR: 2 & HALAMAN: $135-145$ & $\begin{array}{c}\text { ISSN: 2339-0042 (p) } \\
\text { ISSN: 2528-1577 (e) } \\
\text { DOI: 10.24198/share.v10i1.26896 }\end{array}$ \\
\hline
\end{tabular}

perempuan, yang mempertimbangkan karakter moral korban, perilaku atau perbuatan korban di waktu kejadian perkara, dan ketepatan laporan korban ke polisi. Hal serupa ditemukan Maryam (2017), menambahkan fakta bahwa penyelesaian kasus dapat dilakukan di luar pengadilan. Namun, penemuan Spears \& Spohn lebih menekankan ke peran tradisional gender ketimbang hubungan korban dengan pelaku tindakan kejahatan. Selain itu, dampak mitos pemerkosaan turut berkontribusi pada perilaku menyalahkan korban yang dilakukan tenaga profesional kesehatan mental, menurut penemuan Campbell \& Raja (1999). Penelitian yang dilakukan Maier (2012) terhadap perawat yang terlatih khusus dalam penanganan kekerasan seksual juga mengindikasikan kepercayaan mereka bahwa polisi, tenaga medis, atau pihak berwajib melakukan reviktimisasi korban kekerasan seksual.

Mitos pemerkosaan (rape myths) menggambarkan bagaimana peran tradisional memengaruhi kekeliruan pengatribusian kesalahan kepada korban kekerasan seksual terhadap perempuan, yang tentu saja menjelaskan konsekuensi nilai-nilai budaya tanpa memandang jabatan orang ketiga selaku pengamat kasus ini. Perempuan dituntut paham atas apa yang harus dan tidak harus dilakukannya sebagai individu yang terlahir dengan jenis kelamin tersebut.

\section{Kepercayaan pada Dunia yang Adil (Just World Beliefs)}

Kepercayaan seseorang mendapatkan sesuatu yang sepatutnya diperoleh (just world beliefs) berkesinambungan dengan mitos pemerkosaan (rape myths). Menurut Lonsway \& Fitzgerald (1994), mitos pemerkosaan adalah contoh dari fenomena kepercayaan pada dunia yang adil. Kepercayaan ini berlandaskan persepsi manusia yang melihat dunia sebagai tempat yang aman, bahwa hal-hal yang baik hanya terjadi kepada orang-orang yang baik pula, begitu pun sebaliknya (The Canadian Resource Centre for Victims of Crime, 2009; Yamawaki, 2009). Jadi, korban kekerasan seksual terhadap perempuan secara otomatis disangka berperilaku buruk, tidak pantas, dan mengundang celaka bagi dirinya sendiri.
Kurangnya empati kepada korban
kekerasan seksual terhadap perempuan menyumbangkan pengaruh besar pada persepsi ini. Hal ini digambarkan oleh minimnya rasa iba yang dikeluarkan laki-laki pada korban karena mereka terlebih dahulu memunculkan rasa protektif untuk kelompok mereka. Sebaliknya, perempuan cenderung lebih berpihak pada korban disebabkan oleh: 1) rasa in-group yang berkembang antar sesama perempuan; dan 2) memiliki pengalaman yang sama atau serupa dengan korban (Bongiorno et al., 2010; Gray et al., 2010; Lonsway \& Fitzgerald, 1994). Sebuah penelitian yang dilakukan Perilloux et al. (2014) terhadap anggota perempuan dari organisasi di sebuah universitas mengungkapkan bahwa orang ketiga dengan kriteria: 1) melaporkan kasus pelecehan seksual terhadap perempuan; 2) pernah mengalami viktimisasi seksual; dan 3) mengetahui seorang perempuan yang pernah mengalami viktimisasi seksual, lebih mudah berempati terhadap korban. Meskipun demikian, peneliti berpikir keadaan-keadaan tersebut tidak berlaku setiap saat. Mengetahui sifat manusia yang dinamis, kadar rasa empati mereka mudah sekali mengalami naik-turun pada situasi tertentu.

Berhubungan dengan bias yang tumbuh di benak orang ketiga dengan korban kekerasan seksual, misalnya, figur publik dan orang yang pernah berperilaku buruk padanya di masa lalu, tampaknya menaikkan derajat pertanggungjawaban dalam kasus ini atas kesan kurang baik terhadap mereka. Saat ini, konsep berempati perempuan bersama kelompok mereka mengabur, meninggalkan pandangan bahwa di waktu inilah korban-korban menebus kesalahan mereka demi terciptanya dunia yang adil. Tentunya, hal semacam ini sudah tidak sesuai dengan konteks aslinya. Dengan laki-laki pun berlaku hal serupa. Seperti di dalam salah satu pembahasan tentang mitos pemerkosaan, makna peran gender yang perlahan bergeser dari tradisional ke kontemporer menghadirkan ancaman dan rasa tidak aman bagi laki-laki. Mereka kemudian mengatribusikan kesalahan pada korban untuk menjustifikasi kerapuhan mereka.

Sebuah penelitian yang dilakukan Yamawaki (2009) di negara-negara Barat menunjukkan bahwa laki-laki dengan 


\begin{tabular}{|c|c|c|c|c|}
\hline Share: Social Work Jurnal & VOLUME: 10 & NOMOR: 2 & HALAMAN: $135-145$ & $\begin{array}{c}\text { ISSN: 2339-0042 (p) } \\
\text { ISSN: 2528-1577 (e) } \\
\text { DOI: 10.24198/share.v10i1.26896 }\end{array}$ \\
\hline
\end{tabular}

kepercayaannya pada dunia adil yang tinggi cenderung lebih banyak menyalahkan korban kekerasan seksual terhadap perempuan, berbanding terbalik dengan perempuan yang semakin tinggi tingkat kepercayaannya, maka mereka cenderung lebih sedikit menyalahkan korban. Seperti yang telah diungkapkan sebelumnya, laki-laki dengan kepercayaan tingginya pada dunia yang adil berusaha membantu kerapuhan diri mereka, dan perilaku tersebut mampu memuaskan keadaan psikologis mereka. Dengan perempuan, kepercayaannya pada dunia yang adil menjadi andilnya lebih sedikit menyalahkan korban karena mereka kurang lebih mengharapkan keadilan bagi korban. $\mathrm{Hal}$ ini tentu dirasakan oleh mereka yang pernah mengalami kasus serupa, meskipun tidak menutup kemungkinan juga bagi yang mampu menaruh setidaknya simpati untuk korban.

Sebuah asumsi berkenaan dengan kebebasan individu menganut apa pun yang dipercayainya, termasuk menganggap seseorang mendapatkan sesuatu yang sepatutnya diperoleh dan dunia merupakan tempat yang adil, menghasilkan sebuah perkiraan bahwa korban kekerasan seksual terhadap perempuan juga mengakui kebenaran pandangan negatif perilakunya. Hal ini bisa berawal dari konformitas mayoritas masyarakat sehingga nilai tersebut digeneralisasi sedemikian rupa. Korban perlahan menyadari dan mulai menganalisis kepantasan mereka sebagai korban akibat perbuatan mereka sendiri. Sebuah penelitian yang dilakukan Perilloux et al. (2014) mengungkapkan bahwa korban kekerasan seksual terhadap perempuan yang ikut menyalahkan diri mereka sendiri mempunyai keterkaitan dengan mekanisme koping mereka. Konsep korban "pantas" yang terinternalisasi di benak mereka (misalnya, pengaruh alkohol, pakaian terbuka, keluar rumah sendirian di malam hari) menimbulkan segenap perasaan bisa mengendalikan situasi, sebagai ancang-ancang ketika bertemu kondisi serupa di masa depan. Mereka turut menyesali apa yang seharusnya bisa dicegah di kejadian lampau. Bongiorno et al. (2014) dalam studinya juga mengungkapkan hal serupa.

Kepercayaan pada dunia yang adil (just world beliefs) menampilkan bagaimana proses pengatribusian kesalahan kepada korban kekerasan seksual terhadap perempuan berawal dari ketidakinginan individu menghadapi hal-hal yang berada di luar kontrolnya, ditandai dengan kurangnya rasa empati hingga berujung menyalahkan diri sendiri atas peristiwa keji yang menimpanya.

\section{SIMPULAN DAN SARAN}

Teori atribusi memperlihatkan bagaimana manusia memanfaatkan keterampilan kognitifnya untuk menghasilkan hubungan kausalitas atau sebab-akibat, menginterpretasi sesuatu seperti perilaku di sekitarnya berdasarkan pemahaman (seperti, pengaruh nilai-nilai budaya) yang dimilikinya terhadap suatu hal tersebut. Namun, tidak semua pengatribusian sesuatu mengarah ke kebijaksanaan pengambilan keputusan. Pada tulisan ini, contohnya, dengan memberi label negatif tertentu atau menyalahkan korban (victim blaming) kekerasan seksual terhadap perempuan malah berdampak buruk pada keadaan psikologis korban, kemudian memengaruhinya untuk sembuh dari kejadian traumatis.

Dua faktor penting yang memengaruhi manusia dan kecenderungannya menyalahkan korban adalah mitos pemerkosaan (rape myths) dan kepercayaan pada dunia yang adil (just world beliefs). Tidak bisa dimungkiri, kedua hal ini saling berkaitan satu sama lain dan bergantung pada nilai-nilai budaya yang melekat di setiap individu. Contoh dari mitos pemerkosaan ialah peran tradisional gender, menunjukkan adanya susunan aturan-aturan mengenai bagaimana mereka harus bertindak, berpakaian, berbicara, dan berperilaku berdasarkan jenis kelamin mereka. Standar ganda berlaku untuk laki-laki dan perempuan harus merasakan sejumlah tekanan. Rasa terancamnya laki-laki dari peran tradisional yang bergeser tadi menyebabkan hadirnya sejumlah hukuman yang harus ditebus perempuan, atau kepercayaan pada dunia yang adil, demi menjustifikasi kerapuhan diri mereka (Maryam, 2017).

Mengurangi perilaku menyalahkan korban dapat dimulai dari sejenis pelatihan untuk pihakpihak berwajib, karena sejatinya mereka adalah pihak yang diharapkan berlaku netral tanpa menghakimi korban dengan landasan nilai-nilai budaya, juga tempat korban memperjuangkan keadilannya. Selain itu, kesadaran masyarakat dapat dibangun dengan publikasi-publikasi seperti 


\begin{tabular}{|c|c|c|c|c|}
\hline Share: Social Work Jurnal & VOLUME: 10 & NOMOR: 2 & HALAMAN: $135-145$ & $\begin{array}{c}\text { ISSN: 2339-0042 (p) } \\
\text { ISSN: 2528-1577 (e) } \\
\text { DOI: 10.24198/share.v10i1.26896 }\end{array}$ \\
\hline
\end{tabular}

tulisan ini, video-video edukatif yang disajikan melalui televisi maupun internet, dan pengajaran langsung dari acara seminar. Rencana intervensi ini harus dilakukan secara berkala layaknya manusia menginternalisasikan nilai-nilai budaya dalam kehidupannya. Namun, peneliti tidak bisa menjamin signifikansi yang dihasilkan dari aktivitas-aktivitas tersebut. Walaupun begitu, Rusyidi et al. (2020) membuktikan intervensi kegiatan melalui pelatihan selama 4 minggu berturut-turut terhadap 67 mahasiswa di suatu universitas mampu memengaruhi kerangka berpikir mereka terhadap kekerasan seksual, khususnya berkenaan dengan mitos pemerkosaan (rape myths), secara signifikan. Misalnya, mereka menjadi lebih gampang menolak penilaian berdasarkan mitos pemerkosaan, mampu mengidentifikasi bahwa kekerasan seksual tidak hanya menyerang fisik korban, dan tidak menerima pemerkosaan sebagai aksi pembalasan dendam pelaku terhadap korban.

Dalam hal berhubungan dengan hukum, Oktaviani \& Azeharie (2020) menyebutkan bahwa korban kekerasan seksual maupun pelecehan seksual dapat melibatkan kelompok hard core, yakni orang-orang yang tidak terpengaruh dengan perilaku menyalahkan korban (victim blaming) Komisi Nasional Anti Kekerasan terhadap Perempuan, aktivis, pendamping, dan penyintas atau korban. Oktaniani \& Azeharie menunjukkan praktik tersebut membantu korban agar tidak merasa sendiri lagi dan mempercepat proses pemulihan diri.

\section{UCAPAN TERIMA KASIH}

Pertama-tama, peneliti ingin berterima kasih sebesar-besarnya kepada Allah SWT karena atas rahmat dan karunia-Nya, peneliti dapat merampungkan artikel jurnal ini. Selanjutnya, ilmu-ilmu yang diperoleh semasa mengerjakan artikel dan argumentasi yang dipaparkan di sini tidak mungkin ada tanpa peneliti-peneliti sebelumnya yang dijadikan acuan untuk penulisan. Terakhir, peneliti mengucapkan terima kasih untuk dosen pembimbing, Ibu Dr. Nurliana Cipta Apsari, S.Sos., M.SW. dan Ibu Dra. Hetty Krisnani, M.Psi., atas bimbingannya dalam mengerjakan artikel.

\section{DAFTAR PUSTAKA}

Abrams, D., Viki, G. T., Masser, B. \& Bohner, G. (2003). Perceptions of Stranger and Acquaintance Rape: The Role of Benevolent and Hostile Sexism in Victim Blame and Rape Proclivity. Journal of Personality and Social Psychology, 84(1), 111125. doi: $10.1037 / 0022-3514.84 .1 .111$

Amandasari, D. B. \& Margaretha. (2019). Ambivalent Sexism, Attribution of Blame to the Victim and Perceptions about Victims of Violence in Relationships. Anima, 34(3), 125-135. doi: 10.24123/aipj.v34i3.2301

Anisa \& Santoso, M. B. (2020). Advokasi Pekerja Sosial Terhadap Korban Kekerasan Seksual terhadap Perempuan Dalam Situasi Bencana. Prosiding Penelitian \& Pengabdian Kepada Masyarakat, 7(1), 208-217. Retrieved from http://journal.unpad.ac.id/prosiding/article/downl oad/22881/pdf

Bongiorno, R., Langbroek, C., Bain, P. G., Ting, M. \& Ryan, M. K. (2020). Why Women Are Blamed for Being Sexually Harassed: The Effects of Empathy for Female Victims and Male Perpetrators. Psychology of Women Quarterly, 44(1), 11-27. doi: 10.1177/0361684319868730

Campbell, R. \& Raja, S. (1999). Secondary Victimization of Rape Victims: Insights from Mental Health Professionals Who Treat Survivors of Violence. Violence and Victims, 14(3), 261-275. doi: 10.1891/0886-6708.14.3.261

Catatan Tahunan (CATAHU) Komnas Perempuan. (2020). Kebijakan Penghapusan Kekerasan Seksual untuk Membangun Ruang Aman Bagi Perempuan dan Anak Perempuan. Retrieved from http://komnasperempuan.go.id/file/pdf file/2020/ Catatan\%20Tahunan\%20Kekerasan\%20Terhadap \%20Perempuan\%202020.pdf

George, W. H. \& Martinez, L. J. (2002). Victim Blaming in Rape: Effects of Victim and Perpetrator Race, Type of Rape, and Participant Racism. Psychology of Women Quarterly, 26, 110-119. doi: 10.1111/1471-6402.00049

Gravelin, C. R., Biernat, M. \& Bucher, C. E. (2019). Blaming the Victim of Acquaintance Rape: Individual, Situational, and Sociocultural Factors. 


\begin{tabular}{|c|c|c|c|c|}
\hline Share: Social Work Jurnal & VOLUME: 10 & NOMOR: 2 & HALAMAN: $135-145$ & $\begin{array}{c}\text { ISSN: 2339-0042 (p) } \\
\text { ISSN: 2528-1577 (e) } \\
\text { DOI: 10.24198/share.v10i1.26896 }\end{array}$ \\
\hline
\end{tabular}

Frontiers in Psychology, 9(2422), 1-22. doi: 10.3389/fpsyg.2018.02422

Gray, N. B., Palileo, G. J. \& Johnson, G. D. (2010). Explaining rape victim blame: $A$ test of attribution theory. Sociological Spectrum: Mid-South Sociological Association, 13(4), 377-392. doi: $10.1080 / 02732173.1993 .9982040$

Guamarawati, N. A. (2009). Suatu Kajian Kriminologis Mengenai Kekerasan terhadap Perempuan dalam Relasi Pacaran Heteroseksual. Jurnal Kriminologi Indonesia, 5(1), 43-55. Retrieved from https://media.neliti.com/media/publications/4 252-EN-suatu-kajian-kriminologis-mengenaikekerasan-terhadap-perempuan-dalam-relasipac.pdf

Fiske, S. T., Cuddy. A. J. C., Glick, P. \& Xu, J. (2002). A Model of (Often Mixed) Stereotype Content: Competence and Warmth Respectively Follow from Perceived Status and Competition. Journal of Personality and Social Psychology, $82(6)$, 878-902. doi: 10.1037//00223514.82.6.878

Harnoko, B. R. (2010). Di Balik Tindak Kekerasan terhadap Perempuan. Muwazah, 2(1), 181-188. Retrieved from http://ejournal.iainpekalongan.ac.id/index.php/Mu wazah/article/view/16

Kartika, B. A. (2015). Mengapa Selalu Harus Perempuan: Suatu Konstruksi Urban Pemenjaraan Seksual Hingga Hegemoni Maskulinitas dalam Film Soekarno. Journal of Urban Society's Arts, 2(1), 35-54. doi: 10.24821/jousa.v2i1.1268

Kopper, B. A. (1996). Gender, Gender Identity, Rape Myth Acceptance, and Time of Initial Resistance on the Perception of Acquaintance Rape Blame and Avoidability. Sex Roles, 34, 8193. doi: $10.1007 / B F 01544797$

Lerner, M. J. \& Simmons, C. H. (1966). Observer's Reaction to the "Innocent Victim": Compassion or Rejection? Journal of Personality and Social Psychology, 4(2), 203-210. doi: 10.1037/H0023562

Lonsway, K. A. \& Fitzgerald, L. F. (1994). Rape Myths: In Review. Psychology of Women Quarterly,
18, 133-164. doi: $10.1111 / \mathrm{j} .1471-$ 6402.1994.tb00448.x

Maier, S. L. (2012). Sexual Assault Nurse Examiners' Perceptions of the Revictimization of Rape Victims. Journal of Interpersonal Violence, 27(2). 287-315. doi: 10.1177/0886260511416476

Martinko, M. J. \& Mackey, J. D. (2019). Attribution Theory: An Introduction to the Special Issue. Journal of Organizational Behavior, 40, 523-527. doi: 10.1002/job.2397

Maryam, R. (2017). Stereotipe dan Mitos dalam Penanganan Kasus Kekerasan terhadap Perempuan. Jurnal Legislasi Indonesia, 14(4), 383-394. Retrieved from https://ejurnal.peraturan.go.id/index.php/jli/article/dow nload/113/pdf

Oktaviani, R. \& Azeharie, S. S. (2020). Penyingkapan Diri Perempuan Penyintas Kekerasan Seksual. Koneksi, 4(1), 98-105. Retrieved from https://jour-

nal.untar.ac.id/index.php/koneksi/article/downloa d/6635/5088

Perilloux, C., Duntley, J. D. \& Buss, D. M. (2014). Blame attribution in sexual victimization. Personality and Individual Differences, 64, 81-86. doi: 10.1016/j.paid.2014.01.058

Rusyidi, B., Bintari, A. \& Humaedi, S. (2020). Sikap Mahasiswa Perguruan Tinggi terhadap Mitos Perkosaan. Prosiding Penelitian \& Pengabdian Kepada Masyarakat, 7(1), 163-172. Retrieved from

http://jurnal.unpad.ac.id/prosiding/article/view/25 $\underline{432}$

Sekscinska, K., Trzcinska, A. \& Maison, D. A. (2016). The Influence of Different Roles Activation on Women's Financial and Consumer Choices. Frontiers in Psychology, 7(365), 1-13. doi: 10.3389/fpsyg.2016.00365

Spears, J. W. \& Spohn, C. C. (1996). The Genuine Victim Prosecutors' Charging Decisions in Sexual Assault Cases. American Journal of Criminal Justice, 20(2), 183-205. doi: 10.1007/BF02886925

Syafe'i, I. (2015). Subordinasi Perempuan dan Implikasinya terhadap Rumah Tangga. Jurnal Studi Keislaman, 15, 143-166. doi: 10.24042/ajsk.v15i1.716 


\begin{tabular}{|c|c|c|c|c|}
\hline Share: Social Work Jurnal & VOLUME: 10 & NOMOR: 2 & HALAMAN: $135-145$ & $\begin{array}{c}\text { ISSN: 2339-0042 (p) } \\
\text { ISSN: 2528-1577 }(e) \\
\text { DOI: 10.24198/share.v10i1.26896 }\end{array}$ \\
\hline
\end{tabular}

The Canadian Resource Centre for Victims of Crime.

(2009). Victim Blaming. Retrieved from

https://crcvc.ca/docs/victim blaming.pdf

United Nations Entity for Gender Equality and the Empowerment of Women. (n.d.). Types of violence against women and girls. Retrieved from https://www.unwomen.org/en/what-we-do/endingviolence-against-women/faqs/types-of-violence

United Nations General Assembly. (1993). Declaration on the Elimination of Violence against Women. Retrieved from http://www.undocuments.net/a48r104.htm

World Health Organization. (2012). Understanding and addressing violence against women. Retrieved from

https://www.who.int/iris/bitstream/10665/77434/1/w $\underline{\text { HO RHR } 12.37 \text { eng.pdf?ua=1 }}$

Yamawaki, N. (2009). The Role of Rape Myth Acceptance and Belief in a Just World on Victim Blame Attribution: A Study in Japan. Psychologia, 52, 163-174. doi: 10.2117/psysoc.2009.163 